\title{
0521. A functional citrulline-arginine-no pathway and nos3 complex is essential to maintain microcirculatory function during endotoxemia
}

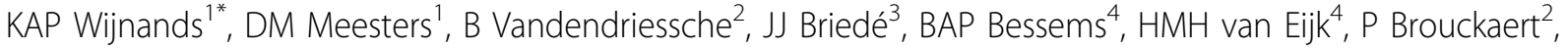 \\ WAP Buurman ${ }^{4}$, A Cauwels $^{2}$, M Poeze $^{1}$
}

From ESICM LIVES 2014

Barcelona, Spain. 27 September - 1 October 2014

\section{Introduction}

Sepsis is associated with high mortality rates as a result of the development of multiple organ failure (MOF). In MOF the competition for the amino acid arginine between the microcirculation and the inflammatory response is important. The endothelial nitric-oxide synthase (eNOS) uses arginine to produce nitric oxide (NO), which results in microcirculatory vasodilatation, whereas arginase and the inflammatory nitric-oxide synthase (iNOS) use arginine in the inflammatory response to produce acute phase proteins and to stimulate the host response. Enhanced arginine consumption combined with decreased arginine de novo synthesis from citrulline results in arginine deficiency for eNOS, eNOS uncoupling, and a decreased organ perfusion.

\section{Objectives}

To investigate the role of the NOS enzymes during endotoxemia and the effect of citrulline supplementation on the arginine-NO synthesis and microcirculation.

\section{Methods}

Wildtype ( $\mathrm{n}=39)$, deficient iNOS mice, $\left(\mathrm{iNOS}^{-1-} ; \mathrm{n}=39\right)$, deficient eNOS mice $\left(\mathrm{eNOS}^{-1-} ; \mathrm{n}=39\right)$ and double knock-out (KO) mice (mice deficient for iNOS and eNOS; $\mathrm{n}=39)$ received a continuous LPS $(200 \mu \mathrm{g}$ total $)$ infusion for $18 \mathrm{hrs}$ alone or combined with citrulline (37.5mg) for the last $6 \mathrm{hrs}$. SDF-imaging was used to evaluate the microcirculation in jejunal villi and the $\mathrm{NO}$ production in jejunal tissue was determined by in vivo NO spin trapping and quantified by electron spin-

${ }^{1}$ Maastricht University Medical Center, Department of Surgery, Maastricht, Netherlands

Full list of author information is available at the end of the article resonance spectrometry. After the microcirculatory measurements or in vivo NO spin trapping, mice were sacrificed, blood and tissues were sampled. Amino-acid concentrations in blood and tissue were measured by High Performance Liquid Chromotography.

\section{Results}

LPS infusion significantly decreased plasma arginine availability in all mouse strains. However, in the jejunal tissue of $\mathrm{iNOS}^{-1-}$ or $\mathrm{eNOS}^{-1-}$ mice this was not accompanied by a decreased intracellular arginine availability. Jejunal NO production was significantly decreased in all mouse strains during endotoxemia, except for eNOS ${ }^{-/-}$mice. LPS infusion resulted in a significantly decrease in jejunal microcirculation in wildtype and iNOS ${ }^{-1-}$ mice. However, mice lacking a functional eNOS enzyme, as present in $\mathrm{eNOS}^{-1-}$ and double $\mathrm{KO}$ mice, perfusion in jejunal tissue did not decrease during LPS infusion. Also the beneficial effects of citrulline supplementation during LPS infusion on the microcirculation were not present in $\mathrm{eNOS}^{-1-}$ or double $\mathrm{KO}$ mice, although citrulline significantly enhanced the plasma arginine availability in all mouse strains. In addition, tissue arginine availability did not increase in citrulline supplemented NOS deficient mice.

\section{Conclusions}

Citrulline improves the arginine de novo synthesis during sepsis, however to enhance the microcirculation during sepsis, citrulline requires a functional eNOS enzyme. Therefore, future research needs to focus both on improvement of the arginine de novo synthesis and maintenance of a functional eNOS enzyme during sepsis. 


\section{Authors' details}

${ }^{1}$ Maastricht University Medical Center, Department of Surgery, Maastricht, Netherlands. ${ }^{2}$ Ghent University, Inflammation Research Center, VIB, Ghent, Belgium. ${ }^{3}$ Maastricht University, Maastricht, Netherlands. ${ }^{4}$ Maastricht

University, Department of Surgery, Maastricht, Netherlands.

Published: 26 September 2014

doi:10.1186/2197-425X-2-S1-P30

Cite this article as: Wijnands et al:: 0521. A functional citrulline-arginineno pathway and nos 3 complex is essential to maintain microcirculatory function during endotoxemia. Intensive Care Medicine Experimental 20142 (Suppl 1):P30.

\section{Submit your manuscript to a SpringerOpen ${ }^{\circ}$ journal and benefit from:}

- Convenient online submission

- Rigorous peer review

- Immediate publication on acceptance

- Open access: articles freely available online

- High visibility within the field

- Retaining the copyright to your article

Submit your next manuscript at $\gg$ springeropen.com 